\title{
PENGARUH PELATIHAN TEHNIK MENYUSUI YANG BENAR PADA IBU NIFAS PRIMIPARA TERHADAP KETRAMPILAN DALAM MENYUSUI
}

\author{
Triwik Sri Mulati, Dewi Susilowati \\ Kementerian Kesehatan Politeknik Kesehatan Surakarta Jurusan Kebidanan
}

\begin{abstract}
The Right Breastfeeding Techniques, Postpartum Primiparous. The purpose of this study was to prove the influence of breastfeeding technique training right at the primiparous postpartum mother breastfeeding skills. This type of research is a Quasi Experimental. Samples are 20 primiparous postpartum mothers in the district of Klaten. Sampling technique is purposive consecutive sampling. Analysis of the data used in this research is to test the Wilxocon. The results of this study are the test results Wilxocon between data pre test and post test 1 shows the $p$ value $=0.000$, where $p<0.05$ which means there is a significant difference between the value of the skills puerperal women primipara before and after given one training technique of right breastfeeding, In addition test results Wilxocon between data post test 1 and post test 2 shows the $p$ value $=0.000$, where $p<0.05$ which means there is a significant difference between the value of the skills postpartum mother primipara after given one training and after a given number of training courses on breastfeeding technique is correct. Therefore it can be concluded that the correct breastfeeding technique training proven to improve the skills of breastfeeding on postpartum mother primipara
\end{abstract}

Keywords: Breastfeeding Technics True, Mother Postpartum primiparityc

Abstrak: Tehnik Menyusui Yang Benar, Ibu Nifas Primipara. Tujuan dari penelitian ini adalah untuk membuktikan pengaruh pelatihan tehnik menyusui yang benar pada ibu nifas primipara terhadap ketrampilan dalam menyusui. Jenis penelitan ini adalah Quasi Eksperimental. Sampel pada penelitian ini adalah 20 ibu nifas primipara di wilayah Kabupaten Klaten. Tehnik pengambilan sampel secara Purposive consecutive sampling. Analisa data yang digunakan dalam penelitian ini adalah uji Wilxocon. Hasil penelitian ini adalah hasil uji Wilxocon antara data pre test dan post test 1 menunjukkan $\mathrm{p}$ value $=0.000$, dimana $\mathrm{p}<0.05$ yang berarti ada perbedaan yang signifikan antara nilai ketrampilan ibu nifas primipara sebelum dan setelah di beri satu kali pelatihan tentang tehnik menyusui yang benar. Selain itu hasil uji Wilxocon antara data post test 1 dan post test 2 menunjukkan $p$ value $=0.000$, dimana $p<0.05$ yang berarti ada perbedaan yang signifikan antara nilai ketrampilan ibu nifas primipara setelah di beri satu kali pelatihan dan setelah di beri dua kali pelatihan tentang tehnik menyusui yang benar. Oleh karena itu dapat disimpulkan bahwa pelatihan tehnik menyusui yang benar terbukti dapat meningkatkan ketrampilan menyusui pada ibu nifas primipara

Kata Kunci: Tehnik Menyusui Yang Benar, Ibu Nifas Primipara 


\section{PENDAHULUAN}

Dewasa ini, menyusui bayi merupakan program pemerintah yang wajib dilakukan oleh ibu nifas karena banyak manfaat dari proses menyusui, baik bagi ibu nifas maupun bagi bayinya. Namun tidak dipungkiri bahwa banyak fakta di masyarakat yang menunjukkan bahwa dalam melakukan proses menyusui sebenarnya tidak mudah, bahkan bayak ibu yang gagal dalam menyusui. Kegagalan dalam menyusui dapat dipengaruhi oleh faktor internal, antara lain: pengetahuan, pendidikan dan pekerjaan ibu, serta faktor eksternal, antara lain promosi susu formula dan tehnik menyusui yang benar. Jika ibu nifas menyusui dengan tehnik yang tidak benar akan menyebabkan terjadinya penyulit dalam proses menyusui. Penyulit tersebut antara lain terjadinya putting susu lecet dan payudara bengkak yang menyebabkan ibu tidak bisa maksimal dalam menyusui bayinya dan bayipun tidak bisa menyusu secara optimal sehingga produksi ASI (Air Susu Ibu) tidak lancar dan bayi tidak mendapat ASI yang berlimpah.

Terjadinya penyulit pada saat dilakukan proses menyusui tentunya akan sangat merugikan ibu maupun bayi. Timbulnya penyulit tersebut diakibatkan oleh beberapa hal, dan yang paling sering muncul adalah puting susu lecet. Ada berbagai faktor yang dapat mempengaruhi keberhasilan menyusui yaitu, faktor ibu $39,7 \%$, faktor bayi $36,7 \%$, teknik menyusui $22,1 \%$, faktor anatomis payudara $1,5 \%$. Suatu contoh kasus sekitar $57 \%$ dari ibu menyusui menderita kelecetan putingnya karena ibu tidak menerapkan tehnik menyusui yang benar. Pada dasarnya gangguan menyusui tersebut dapat dicegah dan diatasi sehingga tidak menimbulkan kesukaran apabila ibu terampil dalam menyusui dengan menerapkan tehnik menyusui yang benar (Depkes , 2008).

Menyusui adalah cara yang optimal dalam memberikan nutirisi dan mengasuh bayi, dan dengan penambahan makanan lengkap pada paruh kedua tahun pertama, kebutuhan nutrisi, imunologi, dan psikososial dapat terpenuhi hingga tahun kedua dan tahun-tahun berikutnya (Gupte, 2004). ASI adalah salah satu zat yang terbaik yang dimiliki manusia sebagai makanan bayi (Gupte, 2004).

Tehnik menyusui adalah suatu cara pemberian ASI yang dilakukan oleh seorang ibu kepada bayinya demi mencukupi kebutuhan nutrisi bayi tersebut (Gupte, 2004). Jika seorang ibu dapat melakukan tehnik menyusui yang benar maka kejadian puting susu lecet dapat dihindari dan bayi dapat menyusu dengan maksimal sehingga produksi ASI pun bisa lancar.

Keterampilan dalam menyusui dengan menerapkan tehnik menyusui yang benar menjadi salah satu faktor penentu apakah proses menyusui itu akan berhasil atau gagal. Keterampilan menyusui berarti ibu nifas dapat menerapkan tehnik menyusui yang benar dengan tepat saat ibu menyusui bayinya. Salah satu kegiatan yang dapat menolong ibu nifas terampil dalam menyusui adalah dengan melatih ibu nifas tentang tehnik menyusui yang benar.

Ibu nifas adalah ibu yang sedang mengalami masa nifas (postpartum) yaitu masa atau waktu sejak bayi dilahirkan dan plasenta keluar lepas dari rahim, sampai enam minggu berikutnya, disertai dengan pulihnya kembali organ-organ yang berkaitan dengan kandungan yang mengalami perubahan seperti perlukaan 
dan lain sebagainya berkaitan saat melahirkan (Juwono, 2004). Sedangkan ibu nifas primipara adalah ibu nifas yang baru pertama kali melahirkan.

Pada kebanyakan ibu nifas primipara masih belum terampil menerapkan tehnik menyusui yang benar karena pengetahuannya masih kurang dan belum berpengalaman dalam menyusui bayinya serta masih jarang tenaga kesehatan yang memberi pelatihan tentang tehnik menyusui yang benar sehingga kemungkinan terjadinya puting susu lecet/penyulit menyusui lainnya (payudara bengkak) cenderung tinggi.

Study pendahuluan yang dilakukan di wilayah Klaten Selatan menunjukkan bahwa dari lima ibu nifas primipara yang sedang menyusui, empat ibu tersebut belum terampil menerapkan tehnik menyusui yang benar dan mengalami puting susu lecet. Ibu nifas primipara yang mengalami puting susu lecet tersebut hampir saja menghentikan proses menyusui bayinya karena kesakitan saat menyusui dan bayi pun tampak tidak puas dalam menyusu karena produksi ASI yang kurang lancar.

Berdasarkan study pendahuluan diatas, para tenaga kesehatan khususnya bidan perlu melakukan suatu pelatihan kepada ibu nifas terutama ibu nifas yang baru pertama kali melahirkan (primipara) supaya mereka terampil dalam menyusui dengan tehnik menyusui yang benar sehingga kejadian puting susu lecet dapat di cegah dan bayi dapat menyusu secara optimal.

\section{METODE PENELITIAN}

Desain penelitian ini adalah quasi eksperiment yaitu studi eksperimental yang dalam mengontrol situasi penelitian menggunakan cara non randomisasi,
Adapun jenisnya adalah one group pre and post test design. Penelitian ini dilaksanakan di BPM (Bidan Praktek Mandiri) di wilayah Klaten. Penelitian ini dilaksanakan pada bulan Januari - Juni 2015. Sampelnya 20 ibu nifas pimipara.

\section{HASIL PENELITIAN}

Tabel 1

Distribusi frekuensi ketrampilan dalam menyusui pada primipara sebelum di beri pelatihan tehnik menyusui yang benar (pre test)

\begin{tabular}{lcc}
\multicolumn{1}{c}{ Kategori } & Frekuensi & Prosentase \\
\hline 1. Baik & - & - \\
2. Cukup & 1 & 5 \\
3. Kurang & 19 & 95 \\
\hline \multicolumn{1}{r}{ Total } & 20 & 100 \\
\hline
\end{tabular}

Tabel 2

Distribusi frekuensi ketrampilan dalam menyusui pada ibu primipara setelah di beri satu kali pelatihan tehnik menyusui yang benar (post test 1)

\begin{tabular}{lcc}
\multicolumn{1}{c}{ Kategori } & Frekuensi & Prosentase \\
\hline 1. Baik & 15 & 75 \\
2. Cukup & 5 & 25 \\
3. Kurang & - & - \\
\hline \multicolumn{1}{c}{ Total } & 20 & 100 \\
\hline
\end{tabular}

$$
\text { Tabel } 3
$$

Distribusi frekuensi ketrampilan dalam menyusui setelah di beri dua kali pelatihan (post test 2)

\begin{tabular}{lcc}
\hline \multicolumn{1}{c}{ Kategori } & Frekuensi & Prosentase \\
\hline 1. Baik & 19 & 95 \\
2. Cukup & 1 & 5 \\
3. Kurang & - & - \\
\hline \multicolumn{1}{c}{ Total } & 20 & 100 \\
\hline
\end{tabular}


Tabel 4

Hasil Statistik Ketrampilan Ibu Nifas
Primipara Sebelum di Beri Pelatihan
dan Setelah di Beri Pelatihan

\begin{tabular}{|c|c|c|}
\hline $\begin{array}{l}\text { Ketrampilan } \\
\text { Menyusui }\end{array}$ & $\mathrm{N}$ & Mean \\
\hline Pre tes & 20 & 39.2 \\
\hline Post tes 1 & 20 & 77.7 \\
\hline Post tes 2 & 20 & 95.8 \\
\hline
\end{tabular}

ketrampilan ibu nifas primipara sebelum di beri pelatihan (pre tes) adalah 39.2, nilai rata rata ketrampilan ibu nifas primipara setelah di beri satu kali pelatihan (post tes 1) adalah 77.7 dan setelah di beri dua kali pelatihan (post tes ke 2) adalah 95.8.

Untuk mengetahui beda rerata antara nilai ketrampilan menyusui pada ibu nifas primipara sebelum dan setelah diberi pelatihan tentang tehnik menyusui yang benar (Post tes 1) maka dilakukan uji Wilcoxon. Hasil uji Wilcoxon menunjukkan $\mathrm{p}$ value $=0.000$, dimana $\mathrm{p}<$ 0.05 yang berarti ada perbedaan yang signifikan antara nilai ketrampilan ibu nifas primipara sebelum di beri pelatihan dengan setelah diberi satu kali pelatihan.

Untuk mengetahui beda rerata antara nilai ketrampilan menyusui pada ibu nifas primipara setelah diberi satu kali pelatihan tentang tehnik menyusui yang benar (Post tes 1) dan dua kali pelatihan (Post tes 2) maka dilakukan uji Wilcoxon. Hasil uji Wilcoxon menunjukkan $\mathrm{p}$ value $=$ 0.000 , dimana $\mathrm{p}<0.05$ yang berarti ada perbedaan yang signifikan antara nilai ketrampilan ibu nifas primipara setelah di beri satu kali pelatihan dengan setelah diberi dua kali pelatihan.

\section{PEMBAHASAN}

Dari hasil uji deskriptif statistik dapat diketahui bahwa nilai rata-rata ketrampilan pada ibu nifas primipara sebelum di beri pelatihan tentang tehnik menyusui yang benar adalah 39.2. Nilai rata-rata ketrampilan pada ibu nifas primipara setelah di beri satu kali pelatihan tentang tehnik menyusui yang benar (post tes 1) adalah 77.7 sedangkan nilai rata rata post tes ke 2 adalah 95.8. Trend nilai menunjukkan kenaikan dari 39.2 menjadi 77.7 pada post tes 1 dan menjadi 95.8 pada post tes 2 membuktikan bahwa ada peningkatan ketrampilan menyusui pada ibu nifas primipara setelah diberi pelatihan tentang tehnik menyusui yang benar. Hal tersebut didukung dari hasil uji Wilxocon antara data pre test dan post test 1 yang menunjukkan $\mathrm{p}$ value $=0.000$, dimana $\mathrm{p}<$ 0.05 yang berarti ada perbedaan yang signifikan antara nilai ketrampilan ibu nifas sebelum dan setelah di beri satu kali pelatihan tentang tehnik menyusui yang benar. Selain itu juga didukung dengan hasil uji Wilxocon antara data post test 1 dan post test 2 yang menunjukkan $p$ value $=0.000$, dimana $\mathrm{p}<0.05$ yang berarti ada perbedaan yang signifikan antara nilai ketrampilan ibu nifas setelah di beri satu kali pelatihan dan setelah di beri dua kali pelatihan tentang tehnik menyusui yang benar, sehingga dapat disimpulkan bahwa pelatihan tehnik menyusui yang benar terbukti dapat meningkatkan ketrampilan menyusui pada ibu nifas primipara.

\section{KESIMPULAN DAN SARAN}

Ada perbedaan rerata skor ketrampilan ibu nifas primipara dalam menyusui sebelum dan sesudah dilakukan 1 kali pelatihan tehnik menyusui yang benar. 
Ada perbedaan rerata skor ketrampilan ibu nifas primipara dalam menyusui setelah dilakukan 1 kali pelatihan tehnik menyusui yang benar dan setelah dilakukan 2 kali pelatihan teknik menyusi yang benar.

Para ibu lebih aktif bertanya dan mencari informasi tentang tehnik menyusui yang benar dan kemudian juga aktif berlatih menerapkan ketrampilan menyusui dengan tehnik yang benar.

Petugas kesehatan khususnya Bidan diharapkan dapat meningkatkan pendidikan kesehatan dan pelatihan tentang tehnik menyusui yang benar.

\section{DAFTAR RUJUKAN}

Bobak, M \& Irene, (2004), Keperawatan maternitas, Edisi 4, Jakarta: EGC

Depkes RI dan JICA, 2008, Kesehatan ibu dan anak, Jakarta ,
Gupte, Suraj M,D, 2004, Panduan keperawatan anak, Jakarta: Pustaka Populer,

Hikmawati, I,, 2008, Faktor-faktor risiko kegagalan pemberian ASI selama dua bulan (studi kasus pada bayi umur 3-6 bulan di kabupaten banyumas) Semarang: Universitas Diponegoro

Juwono, 2004, Persiapan menghadapi persalinan, Jakarta: Mitra Pustaka,

Melvyn, 2006, Anatomi dan dan fisiologi untuk bidan, Jakarta : EGC,

Murkoff, H,, 2006, Kehamilan: apa yang anda hadapi bulan per bulan, Edisi 3, Jakarta: Arcan

Notoatmodjo, S, , 2007, Metodologi penelitian kesehatan, Jakarta: PT, Rineka Cipta 